\title{
KEMATANGAN KARIER SISWA SMK DITINJAU DARI JENIS KELAMIN DAN JURUSAN
}

\author{
Ika Zenita Ratnaningsih, Erin Ratna Kustanti, Anggun Resdasari Prasetyo, \\ Nailul Fauziah \\ Fakultas Psikologi Universitas Diponegoro \\ Jl. Prof Soedharto SH Tembalang Semarang \\ ikazenita@undip.ac.id
}

\begin{abstract}
Background of the high rate of unemployment from SMK graduates supposed by lack of job readiness due to lack of career maturity. This study aims to determine differences in career maturity among Vocational High School (SMK) Students by gender and study major. Career maturity is the individual's success in completing tasks typical career development at each stage of development which is shown by the behavior of individual career conformity with the career expected behavior. Subjects numbered 339 class XI student of SMK, from six vocational schools in Semarang consisting of three state SMK and three private SMK. Subjects consist of 101 male and 238 female with around 15-19 years old. Sampling technique used is purposive sampling. Intrument that used in this study is the Career Maturity Scale and demographic questionnaire. Results of this study by two way ANAVA showed no differences in career maturity in terms of gender and no differences career maturity based on major. Discussions and recommendations are discussed further.
\end{abstract}

Keywords : career maturity, gender, vocational high school

\begin{abstract}
Abstrak
Tingginya angka pengangguran pada lulusan SMK salah satunya dilatarbelakangi oleh belum adanya kesiapan kerja yang disebabkan karena kurangnya kematangan karier. Penelitian ini bertujuan untuk mengetahui perbedaan kematangan karier ditinjau dari jenis kelamin, jurusan dan status sekolah pada siswa Sekolah Menengah Kejuruan (SMK) di Kota Semarang. Kematangan karier adalah keberhasilan individu dalam menyelesaikan tugas perkembangan karir yang khas di setiap tahap perkembangan yang ditunjukkan dengan kesesuaian perilaku karir individu dengan perilaku karir yang diharapkan. Subjek penelitian berjumlah 339 siswa kelas XI SMK dari enam SMK di Kota Semarang yang terdiri dari tiga SMK Negeri dan tiga SMK Swasta yang terdiri dari 101 laki-laki dan 238 perempuan dengan usia subjek berkisar antara 15-19 tahun. Terdapat sepuluh jurusan peminatan yang terlibat dalam penelitian ini Teknik sampling yang digunakan adalah purposive sampling. Alat ukur yang digunakan dalam penelitian ini adalah Skala Kematangan Karier dan kuesioner data demografi. Hasil pengujian hipotesis menggunakan ANAVA dua jalur menujukkan tidak ada perbedaan kematangan karier ditinjau dari jenis kelamin dan tidak ada perbedaan kematangan karier ditinjau dari jurusan. Diskusi dan rekomendasi di bahas selanjutnya.
\end{abstract}

Kata Kunci : jenis kelamin, kematangan karier, smk 


\section{Pendahuluan}

Sebagai sekolah yang dirancang untuk menyiapkan lulusan siap kerja, Sekolah Menengah Kejuruan (SMK) mengemban amanat terkait dengan pendidikan dan pengembangan kemampuan siswa untuk melaksanakan jenis pekerjaan tertentu (PP No.29 th 1990). Meskipun demikian, SMK juga menyumbang jumlah pengangguran yang besar di Indonesia (Jefriando, 2016). Angka pengangguran yang terjadi pada lulusan SMK disebabkan oleh beberapa faktor, yaitu sempitnya lapangan pekerjaan, kesiapan kerja dari siswa lulusan SMK, dan minimnya kompetensi keahlian yang dimiliki. Masalah belum adanya kesiapan kerja lebih disebabkan karena kurangnya kematangan karier, yaitu suatu kondisi dimana para siswa SMK mampu menyelesaikan tugas-tugas perkembangan karier sesuai dengan tahapan yang dilaluinya. Hal itu senada dengan hasil penelitian yang dilakukan Prahesty \& Mulyana (2013) di kota Surabaya yang mendapati adanya perbedaan kematangan karier antara siswa SMA, MA, dan SMK, kematangan karier siswa SMK merupakan yang paling rendah dibandingkan siswa SMA dan MA, dikarenakan sulitnya jurusan yang ditekuni. Di kota Semarang, sampai saat ini penyediaan lapangan kerja masih belum seimbang karena angkatan kerja baru baik lulusan SMK dan lulusan perguruan tinggi jumlahnya meningkat setiap tahun (Karningsih, 2013).

Siswa SMK pada umumnya berada pada usia 15-18 tahun, menurut tahap perkembangan karir pada usia tersebut mulai memasuki fase pertumbuhan dan eksplorasi (Bardick, Kerry, Magnusson, \& Kim, 2006). Berdasarkan tugas perkembangan karier, pada fase ini para siswa dikatakan telah mencapai kematangan karier bila mampu untuk mulai menunjukkan minat terhadap pilihan karier, mulai mengeksplorasi kemampuan diri dan pengetahuan tentang pilihan karier, dan sudah menentukan pilihan meskipun belum pasti dan mulai membuat perencanaan karier. Dalam peneltian terhadap 380 siswa SMK di Bandung, didapatkan bahwa sebagian besar siswa berada pada kategori belum matang Sudjani (2014). Penelitian Tjalla, Heru \& Kustandi (2015) juga menemukan bahwa siswa SMK belum memiliki kematangan karir ditandai dengan tidak dimilikinya perencanaan karier dan informasi yang minimal, kurangnya informasi komprehensif seperti kelompok pekerjaan dan bagaimana untuk membuat keputusan karier.

Karier merupakan masalah yang penting dalam kehidupan manusia yang mencakup perkembangan dari proses pengambilan keputusan yang berlangsung seumur hidup (Crites, dalam Suherman, 2008). Mempersiapkan karier merupakan salah satu tugas perkembangan yang harus dicapai manusia pada usia remaja (Havighurst, dalam Hurlock, 2003). Kegiatan persiapan karier terdiri dari beberapa tahap perkembangan karier yang menentukan pilihan karier remaja selanjutnya. Menurut Super (dalam Winkel, 2012) terdapat lima fase perkembangan karier manusia, yaitu fase pengembangan (growth), fase eksplorasi (exploration), fase pemantapan (establishment), fase pembinaan (maintenance), dan fase kemunduran (decline). Fase pengembangan dimulai dari masa anak-anak sampai usia 15 tahun, pada tahapan ini ditandai dengan pembentukan konsep diri, yang muncul karena adanya proses pengembangan potensi, sikap minat dan kebutuhankebutuhan. Fase eksplorasi dimulai antara umur 16 - 24 tahun, pada tahapan ini individu mampu mengumpulkan informasi karier yang relevan dan mengembangkan 
keterampilan terkait. Fase pemantapan dimulai antara umur 25- 44 tahun, ditandai dengan pemantapan diri pada sebuah karier. Fase pembinaan dimulai antara umur 4565 tahun, pada fase ini proses penyesuaian terus berlanjut untuk meningkatkan jenjang karier. Fase kemunduran terjadi pada usia 65 tahun keatas ditandai dengan persiapan masa pensiun. Keberhasilan individu dalam menyelesaikan tugas perkembangan karier yang khas bagi tahap perkembangan tertentu disebut juga dengan kematangan karier (Gonzales, 2008).

Kematangan karier terkait dengan seberapa baik remaja mengatasi masalah terkait tugas perkembangan karier, yaitu kristalisasi, spesifikasi dan implementasi pilihan karier (Hughes, 2011). Brown \& Lent (2005) mengemukakan bahwa kematangan karir merupakan konstruk psikologis yang berupa kontinum tahapan karir dari mulai pertumbuhan hingga pelepasan karir. Hal tersebut erat kaitannya dengan tugas perkembangan dan harapan yang didasarkan pada usia kronologis. Super (dalam Winkel, 2012) menyebutkan bahwa kematangan karir merupakan keberhasilan individu dalam menyelesaikan tugas perkembangan karir yang khas di setiap tahap perkembangan yang ditunjukkan dengan kesesuaian perilaku karir individu dengan perilaku karir yang diharapkan.

Terdapat beberapa faktor yang mempengaruhi kematangan karir, Winkel \& Hastuti (2004) menyebutkan adanya faktor internal dan eksternal yang mempengaruhi kematangan karir. Faktor internal terdiri dari nilai kehidupan, taraf inteligensi, bakat khusus, minat, sifat kepribadian, pengetahuan, dan keadaan jasmani. Faktor eksternal diantaranya adalah masyarakat, kondisi sosial-ekonomi negara atau daerah, status sosial-ekonomi keluarga, pengaruh keluarga besar dan inti, pendidikan di sekolah, rekan sebaya, tuntutan yang melekat pada jabatan atau program studi. Di sisi lain, Patton \& Lokan (2001) menyebutkan faktor yang mempengaruhi kematangan karier remaja diantaranya adalah usia, jenis kelamin, status sosioekonomi, materi beajar, budaya, peran khas, kemampuan mengarahkan diri, keraguan karir, dan pengalaman bekerja. Osipow (1996) menyebutkan bahwa usia, jenis kelamin, status sosial ekonomi, dan perbedaan ras dan budaya berhubungan dengan kematangan karier. Powell \& Luzzo (1998) bahwa kematangan karier atau yang sering disebut juga sebagai kematangan vokasional berhubungan dengan variabel demografis seperti jenis kelamin, umur, tingkat kelas, dan etnis.

Pendidikan di sekolah merupakan salah satu faktor eksternal yang dapat memberikan pengaruh pada kematangan karier individu (Winkel \& Hastuti, 2004). Sirohi (2013) dalam penelitian yang dilakukan di India mendapati bahwa jenis kelamin, jenis sekolah dan bimbingan karir serta persepsi siswa tentang bimbingan karir di sekolah mempengaruhi kematangan karir para siswa. Riset terdahulu tentang kematangan karier menyebutkan bahwa kematangan karier yang tinggi berhubungan dengan harga diri, pusat kendali internal dan nilai kerja intrinsik (Khan, dalam Dhillon \& Kaur, 2005). Semakin tinggi harga diri yang dimiliki individu akan mempengaruhi identitas karier individu. Powell dan Luzzo yang meneliti hubungan kematangan karier dan gaya pengambilan keputusan karier pada siswa sekolah menengah menemukan bahwa siswa yang memiliki kontrol terhadap keputusan karier yang diambil menunjukkan sikap positif terhadap proses pengambilan keputusan karier dan memiliki kesadaran yang lebih tinggi terhadap karier (Prideaux \& Creed, 2001). Penelitian Salami 
(2004) menunjukkan bahwa kemampuan pemecahan masalah dapat memprediksi kematangan karier pada siswa sekolah lanjutan. Denga (dalam Amadi, Joshua \& Agaswara, 2007) menyebutkan bahwa ketidakmatangan karier memberi kontribusi pada referensi vokasional dan pengambilan keputusan yang tidak realistik pada siswa. Beberapa penelitian tersebut mendasari bahwa kajian mengenai kematangan karier merupakan hal yang penting untuk diteliti.

Pada penelitian ini peneliti bermaksud melakukan penelitian komparatif dengan membandingkan kematangan karier ditinjau dari variabel demografi seperti jenis kelamin dan jurusan yang diambil. Penelitian terdahulu tentang perbedaan kematangan karier ditinjau dari jenis kelamin sudah pernah dilakukan namun terdapat hasil yang berbeda. Busacca \& Taber (2002) dalam penelitiannya mengemukakan bahwa perempuan cenderung untuk lebih dewasa dalam karir daripada laki-laki. Salami (2008) menemukan bahwa status identitas secara signifikan memprediksi kematangan karir remaja, namun jenis kelamin bukanlah sesuatu yang dapat memprediksi. Sementara it Ottu \& Idowu (2014) melakukan penelitian di Ibadan Nigeria mendapati bahwa kematangan karier siswa lakilaki lebih tinggi dari siswa perempuan. Terdapat pendapat bahwa banyaknya pengangguran di Indonesia dari lulusan SMK dikarenakan belum adanya lapangan kerja yang menampung (Jefriando, 2016), hal tersebut diduga dipengaruhi oleh salah satu faktor eksternal yang mempengaruhi kematangan karier yaitu tuntutan yang melekat pada jabatan atau program studi (Winkel \& Hastuti, 2004). Oleh karena itu dalam penelitian ini peneliti bermaksud ingin melihat perbedaan kematangan karier pada beberapa jurusan yang ada di SMK.

\section{Metode Penelitian}

Penelitian ini melibatkan 339 subjek yang merupakan siswa kelas XI yang berasal dari enam SMK di Kota Semarang, yang terdiri dari tiga SMK Negeri $(55,75 \%)$ dan tiga SMK Swasta $(44,24 \%)$ serta 10 jurusan peminatan yaitu administrasi perkantoran(16,81\%), akomodasi perhotelan (13\%), akuntansi $(17,1 \%)$, kecantikan rambut $(7,7 \%)$, multimedia $(7,4 \%)$, pemasaran $(10,6 \%)$, tata busana $(3,5 \%)$, teknik audio video $(8,6 \%)$, teknik kendaraan ringan $(9,1 \%)$, teknik komputer dan jaringan (6,2\%). Subjek terdiri dari 101 laki-laki dan 238 perempuan. Usia subjek berkisar antara 15-19 tahun. Teknik sampling yang digunakan adalah non probability sampling yaitu purposive sampling (Sugiyono, 2005). Kriteria rekrutmen yang digunakan adalah, subjek berada pada kelas XI di SMK.

Penelitian ini menggunakan metode penelitian kuantitatif dengan pendekatan survey pada siswa SMK dengan tiga variable. Variabel bebas dalam penelitian ini adalah jenis kelamin, jurusan, sementara variabel terikat dalam penelitian ini adalah kematangan karier. Jenis kelamin dibedakan menjadi laki-laki dan perempuan. Jurusan dibedakan menjadi sepuluh kelompok yaitu administrasi perkantoran, akomodasi perhotelan, akuntansi, kecantikan rambut, multimedia, pemasaran, tata busana, teknik audio video, teknik kendaraan ringan, serta teknik komputer dan jaringan.

Pengumpulan data dalam penelitian ini menggunakan metode skala untuk mengungkap respon pribadi subjek. Skala yang digunakan adalah Skala Kematangan Karier yang disusun peneliti dengan dasar teori dari Super (dalam Winkel, 2012). Skala Kematangan Karier (43 aitem, $\alpha=$ 0,917) berbentuk likert dengan lima pilihan jawaban yang bergerak antara 1 (Sangat 
Tidak Sesuai) hingga 5 (Sangat Sesuai). Daya diskriminasi aitem berkisar antara 0,323 - 0,601. Skala disusun berdasarkan aspek 1.) Mampu menilai kondisi diri dikaitkan dengan pemilihan pekerjaan, 2.) Berusaha mengeksplorasi informasi pekerjaan, 3.) Dapat membuat perencanaan tentang pekerjaan, dan 4.) Dapat mengambil keputusan dalam pemilihan pekerjaan. Contoh aitem diantaranya, "Meskipun belum merupakan keputusan akhir, Aku sudah memiliki pilihan bidang pekerjaan"; "Aku merasa yakin dengan pilihan karierku di masa mendatang”. Selain itu peneliti juga menggunakan kuesioner data demografi untuk mengetahui jenis kelamin, jurusan, dan asal sekolah. Skala sebelumnya telah diujicobakan pada kelompok subjek yang memiliki karakteristik yang sama dengan subjek penelitian.

Metode analisis data yang digunakan adalah Analisis Varian (ANAVA) dua jalur. untuk menguji hipotesis komparatif dari kelompok sampel. Asumsi yang dipenuhi sebelum melakukan uji hipotesis adalah uji normalitas dan uji homogenitas. Seluruh analisis dilakukan dengan bantuan program komputer SPSS 22.0.

\section{Hasil dan Pembahasan}

Berdasarkan hasil penelitian yang telah dilakukan, statistik deskriptif disajikan pada tabel berikut:

Tabel 1. Statistik Deskriptif

\begin{tabular}{|c|c|c|c|c|c|c|}
\hline & Variabel & $\mathrm{N}$ & Rerata & SD & Minimum & Maksimum \\
\hline \multirow{20}{*}{ Kematangan Karier } & Jenis Kelamin & & & & & \\
\hline & Laki-laki & 101 & 156.78 & 18.336 & 117 & 205 \\
\hline & Perempuan & 238 & 156.78 & 19.493 & 101 & 199 \\
\hline & Total & 339 & 156.78 & 19.128 & 101 & 205 \\
\hline & Jurusan & & & & & \\
\hline & Akomodasi Perhotelan & 44 & 156.66 & 19.522 & 107 & 194 \\
\hline & Teknik Komputer Jaringan & 21 & 157.24 & 15.339 & 117 & 185 \\
\hline & Multimedia & 25 & 148.24 & 16.011 & 118 & 179 \\
\hline & Tata Busana & 12 & 162.50 & 18.510 & 134 & 197 \\
\hline & Administrasi Perkantoran & 57 & 154.32 & 15.584 & 124 & 198 \\
\hline & Akuntansi & 58 & 156.91 & 21.442 & 108 & 199 \\
\hline & Kecantikan Rambut & 26 & 165.77 & 18.824 & 127 & 196 \\
\hline & Teknik Kendaraan Ringan & 31 & 155.13 & 17.935 & 128 & 197 \\
\hline & Teknik Audio Video & 29 & 160.86 & 22.723 & 101 & 205 \\
\hline & Pemasaran & 36 & 156.03 & 20.444 & 114 & 189 \\
\hline & Total & 339 & 156.78 & 19.128 & 101 & 205 \\
\hline & Status Sekolah & & & & & \\
\hline & Negeri & 150 & 155.44 & 17.405 & 108 & 199 \\
\hline & Swasta & 189 & 157.85 & 20.376 & 101 & 205 \\
\hline & Total & 339 & 156.78 & 19.128 & 101 & 205 \\
\hline
\end{tabular}

Dari tabel 1 di atas dapat diketahui bahwa ditinjau dari jenis kelamin, pada kelompok subjek dengan jenis kelamin laki-laki $(\mathrm{N}=101)$, rerata skor kematangan karier yang didapatkan adalah 156,782 (kategori tinggi), hal tersebut sama dengan subjek perempuan $(\mathrm{N}=238)$ rerata skor yang didapatkan adalah 156,782 (kategori tinggi). Hal ini menunjukkan bahwa siswa laki-laki dan siswa perempuan berada pada rentang kategori yang sama. 
Ditinjau dari jurusan, pada kelompok subjek dengan jurusan akomodasi perhotelan $(\mathrm{N}=44)$ rerata skor kematangan karier adalah 156,66 (kategori tinggi), jurusan teknik komputer jaringan $(\mathrm{N}=21)$ rerata skor kematangan karier adalah 157,24 (kategori tinggi), jurusan multimedia $(\mathrm{N}=25)$ rerata skor kematangan karier adalah 148,24 (kategori tinggi), jurusan tata busana $(\mathrm{N}=12)$ rerata skor kematangan karier adalah 162,50 (kategori tinggi), jurusan administrasi perkantoran $(\mathrm{N}=57)$ rerata skor kematangan karier adalah 154,32 (kategori tinggi), jurusan akuntansi $(\mathrm{N}=58)$ rerata skor kematangan karier adalah 156,91 (kategori tinggi), jurusan kecantikan rambut $(\mathrm{N}=26)$ rerata skor kematangan karier adalah 165,77 (kategori tinggi), jurusan teknik kendaraan ringan $(\mathrm{N}=31)$ rerata skor kematangan karier adalah 155,13 (kategori tinggi), jurusan teknik audio video $(\mathrm{N}=29)$ rerata skor kematangan karier adalah 160, 86 (kategori tinggi), jurusan pemasaran $(\mathrm{N}=36)$ rerata skor kematangan karier adalah 156,03 (kategori tinggi). Dilihat dari perbedaan rerata maka yang memiliki kematangan karier paling tinggi adalah siswa dari jurusan kecantikan rambut, hal tersebut dapat dikaitkan dengan gambaran yang pasti mengenai gambaran yang akan digeluti selanjutnya.

Ditinjau dari status sekolah, pada kelompok subjek dari sekolah negeri $(\mathrm{N}=150)$ rerata skor kematangan karier adalah 155,44 (kategori tinggi), sekolah swasta $(\mathrm{N}=189)$ rerata skor kematangan karier adalah 157,85 (kategori tinggi). Dilihat dari perbedaan rerata maka yang memiliki kematangan karier paling tinggi adalah siswa dari sekolah swasta.

Secara keseluruhan $(\mathrm{N}=339)$, rerata yang didapatkan adalah 156,78, dengan deviasi standar 19,128, hal tersebut menunjukkan skor yang tinggi, dilihat dari indikasi rerata empirik lebih besar dari rerata hipotetik. Kategorisasi lebih lanjut diketahui bahwa siswa mayoritas berada pada kategori kematangan karier yang tinggi ( 247 siswa; $72,9 \%$ ), sisanya berada pada kategori sangat tinggi (65 siswa; 19,2\%), dan rendah (27 siswa; $8 \%$ ).

Sebelum dilakukan uji hipotesis, sebelumnya dilakukan uji asumsi dengan melakukan uji normalitas dan uji homogenitas. Uji normalitas dilakukan dengan perhitungan nilai Kolmogorov smirnov, dan uji homogenitas menggunakan levene test. Data diketahui normal ( $\mathrm{K}-\mathrm{Z}=$ $0,2)$ dan homogen $(p=0,206 ; p>0,05)$. Untuk membuktikan hipotesis dilakukan analisis varian (anava) dua jalur. Hasil menunjukkan tidak ada perbedaan kematangan karier ditinjau dari jenis kelamin $(\mathrm{F}=1,176, \mathrm{p}=$ $0,279 ; \mathrm{p}>0,05)$ dan tidak ada perbedaan kematangan karier ditinjau dari jurusan $(F=1,754, p=0,076 ; p>0,05)$. Hasil terlampir pada tabel 2. Dari hasil uji hipotesis tersebut dapat disimpulkan bahwa hipotesis ditolak. Lebih lanjut digambarkan pada gambar 1 tentang grafik kematangan karier ditinjau dari jenis kelamin dan jurusan. Grafik tersebut menunjukkan tidak adanya interaksi.

Tabel 2. Rangkuman Hasil Uji Beda

\begin{tabular}{lcccccc}
\hline & $\begin{array}{c}\text { Jumlah } \\
\text { Kuadrat }\end{array}$ & Db & $\begin{array}{c}\text { Rerata } \\
\text { Kuadrat }\end{array}$ & F & p & $\begin{array}{c}\text { Eta } \\
\text { Squared }\end{array}$ \\
\hline Antar Kelompok & & & & & & \\
Jenis & 423,099 & 1 & 423,099 & 1,176 & 0,279 & 0,004 \\
Kelamin & & & & & & \\
Jurusan & 5680,285 & 9 & 631,143 & 1,754 & 0,076 & 0,046 \\
Kesalahan & 117993,561 & 328 & & & & \\
\hline
\end{tabular}




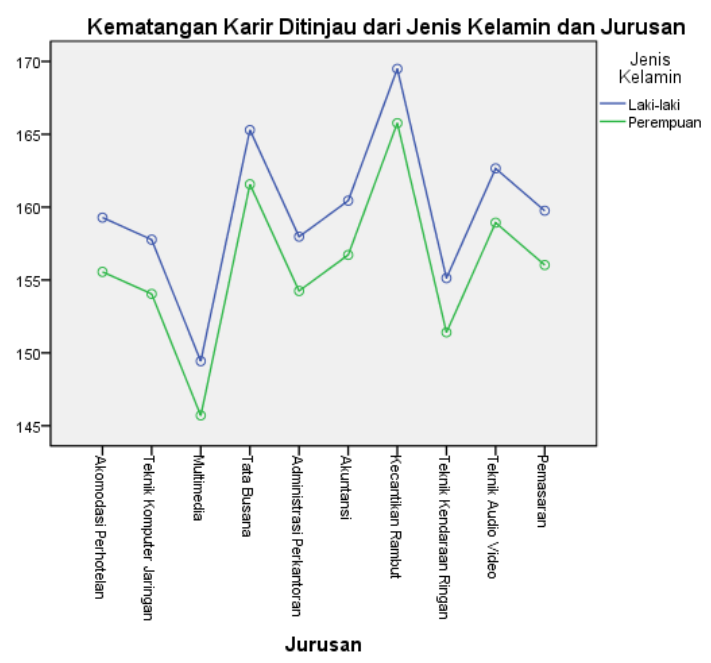

Gambar 1. Gambaran Kematangan Karier ditinjau dari Jenis Kelamin dan Jurusan

Hasil penelitian menunjukkan tidak ada perbedaan kematangan karier siswa SMK ditinjau dari jenis kelamin $(F=1,176, p=0,279 ; p>0,05)$. Hasil tersebut menjelaskan bahwa jenis kelamin bukanlah faktor yang membedakan kematangan karier siswa SMK. Hasil penelitian ini senada dengan penelitian Salami (2008) yang mengemukakan bahwa jenis kelamin bukanlah prediktor dari kematangan karier pada siswa. Birol dan Kiralp (2010) juga menemukan bahwa tidak ada perbedaan kematangan karier jika ditinjau dari jenis kelamin. Namun demikian hasil penelitian ini bertentangan dengan temuan dalam penelitian sebelumnya yang mengemukakan bahwa jenis kelamin memiliki hubungan yang signifikan dengan kematangan karier. Beberapa penelitian menemukan bahwa perempuan memiliki skor kematangan karier yang lebih tinggi daripada laki-laki (Luzzo, 1995; Ariyanti, 2007; Marpaung, 2016).

Penjelasan bahwa hasil penelitian menunjukkan bahwa tidak ada perbedaan antara kematangan karier pada siswa laki-laki dan perempuan dapat dilihat lebih lanjut pada data yang menunjukkan bahwa pada kedua kelompok berada pada kategori kematangan karier yang samasama tinggi. Pada tiap aspek yaitu penilaian kondisi diri dikaitkan dengan pemilihan pekerjaan, eksplorasi informasi terhadap pekerjaan, pembuatan perencanaan tentang pekerjaan dan pengambilan keputusan dalam pemilihan pekerjaan baik pada kelompok siswa perempuan maupun lakilaki berada pada rentang skor yang hampir sama. Skor kematangan karier yang berada kategori tinggi dimungkinkan karena siswa pada pendidikan SMK mendapatkan kesempatan yang besar untuk praktek terkait dengan bidang yang akan ditekuni kemudian di dunia kerja.

Ditinjau dari perbedaan jurusan diketahui tidak ada perbedaan kematangan karier ditinjau dari jurusan peminatan $(F=1,754, p=0,076 ; p>0,05)$, pada umumnya siswa berada pada kategori kematangan karier yang tinggi. Namun demikian, hal yang menarik adalah siswa dengan kematangan karier yang paling tinggi skornya adalah siswa dengan peminatan kecantikan rambut, dan diikuti dengan peminatan tata busana. Sementara itu pada urutan yang terendah adalah siswa dengan peminatan multimedia. Hal ini dapat dijelaskan bahwa pilihan karier siswa pada penjurusan kecantikan rambut maupun tata busana nampak lebih jelas karena terbuka peluang pada kegiatan wirausaha salon maupun penjahit. Peluang kerja nampak spesifik pada bidang usaha salon ataupun tailor. Sementara pada jurusan multimedia, peluang kerja di kota Semarang cenderung belum berkembang dengan pesat.

Tidak adanya perbedaan kematangan karier ditinjau dari jenis kelamin dan jurusan mengindikasikan bahwa ada faktor lain yang turut berkontribusi pada tercapainya kematangan karier pada siswa. Selain jenis 
kelamin sebagai faktor demografis yang bersifat internal, dimungkinkan bahwa ada faktor internal lainnya yang dapat membedakan kematangan karier antara siswa yang satu dengan yang lainnya. Penelitian sebelumnya telah menyebutkan bahwa efikasi diri memiliki pengaruh dalam mencapai kematangan karier siswa. Selain faktor internal, Winkel (2012) menyebutkan bahwa ada faktor eksternal yang mempengaruhi kematangan karier, seperti karakteristik sekolah. Pada penelitian ini diketahui bahwa tidak ada perbedaan yang signifikan kematangan karier ditinjau sepuluh jurusan yang ada. Rerata kematangan karier pada seluruh jurusan masih berada pada kategori tinggi, namun demikian jika ditelaah lebih lanjut antara jurusan multimedia sebagai jurusan dengan rerata kematangan karier terendah dengan jurusan kecantikan rambut dengan rerata kematangan karier tertinggi memiliki rentang yang cukup jauh.

Terdapat beberapa keterbatasan dalam penelitian ini, diantaranya terkait responden. Jumlah responden/subjek masih terbatas karena hanya berasal dari enam sekolah di kota Semarang menyebabkan belum dapat dilakukannya generalisasi hasil pada populasi yang lebih besar. Sehingga masih dimungkinkan untuk melakukan pengambilan data pada lingkup yang lebih luas.

\section{Simpulan}

Hasilnya penelitian menujukkan bahwa tidak ada perbedaan kematangan karier ditinjau dari jenis kelamin ataupun jurusan. Selain jenis kelamin sebagai faktor demografis yang bersifat internal, dimungkinkan bahwa ada faktor internal seperti efikasi diri dan faktor eksternal seperti karakteristik sekolah yang mempengaruhi kematangan karier. Tingginya skor kematangan karier pada siswa SMK perlu dipertahankan dengan memberikan bimbingan karier yang komprehensif. Untuk siswa yang memiliki skor kematangan karier yang rendah, yaitu sebanyak 27 siswa perlu mendapatkan perhatian khusus untuk diberikan program intervensi guna meningkatkan kematangan karier. Saran untuk kajian lebih lanjut perlu dilakukan terkait budaya sekolah dan praktik pelaksanaan bimbingan karir dan dukungan sekolah terhadap kematangan karier siswa. Penelitian selanjutnya juga dapat diperluas pada subjek di jenis sekolah yang berbeda seperti SMA.

\section{Daftar Pustaka}

Amadi, C. C., Joshua, M. T.,\& Asagwara, C. G. (2007). Assesment of the vocational maturity of adolescent students in owerri education zone of Imo State, Nigeria. Journal of Human Ecology, 21, 257-263

Ariyanti, N. (2007). Perbedaan kematangan karier siswa berdasarkan jenis kelamin, kemampuan skolastik dan inteligensi di SMA Laboratorium Universitas Negeri Malang. Skripsi Tidak Dipublikasikan. Malang. Program Bimbingan Konseling Universitas Negeri Malang

Bardick, A., Kerry B. B. , Magnusson, K. C., \& Kim D.W. (2006). Junior high school student's career plans for the future : A Canadian perspective. Journal of Career Development, 32, 250-271.

Birol, C. \& Kiralp, Y. (2016). A comparative analysis of the career maturity level and career indecision of the first 
grade high school students. Procedia Social and Behavioral Sciences, 5 (2010) 2359-2365. doi:10.1016/j. sbspro.2010.07.464

Brown, S. D., \& Lent, R. W. (2005). Career development and counseling. Putting theory and research to work. New Jersey : John Wiley \& Sons, Inc.

Busacca, L. A., \& Taber, B. J. (2002). The Career Maturity Inventory - Revised : A Preliminary Psychometric Investigation. Journal of Career Assesment, 10(4), 441-455. doi:10.1177/1069072702238406

Dhillon, U., \& Kaur, R. (2005). Career maturity of school children. Journal of the Indian Academy of Applied Psychology, 31, 71-76

Gonzales, M. A. (2008). Career maturity : A priority for secondary education. Electronic Journal of Research in Educational Psychology, 6, 749-772

Hughes, C. (2011). A Cross-Cultural Study of Career Maturity in Australia and Thailand. Unpublished Dissertation. School of Health Sciences College of Science, Engineering and Health RMIT University.

Hurlock, E. B. (2012). Psikologi perkembangan: Suatu pendekatan sepanjang rentang kehidupan. Jakarta: Erlangga.

Karningsih. (2013). Analisis penciptaan lapangan kerja di kota Semarang. Jurnal Litbang Provinsi Jawa Tengah, $11(50)$

Jefriando, M. (2016). Banyak lulusan SMK jadi pengangguran, ini analisa BPS. Diunduh dari http:// finance.detik.com/berita-ekonomi- bisnis/d-3203960/banyak-lulusansmk-jadi-pengangguran-ini-analisabps pada 8 Agustus 2016

Luzzo, D. A. (1995). Gender differences in college students' career maturity and perceived barriers in career development. Journal of Counseling \& Development, 73, 319-322

Marpaung, D. N. (2016). Kematangan karir siswa SMU di Banda Aceh ditinjau dari jenis kelamin dan jenis sekolah. Skripsi Tidak Dipublikasikan. Banda Aceh. Program Studi Psikologi Fakultas Kedokteran Universitas Syiah Kuala.

Osipow, S.H. (1996). Theories of career development. 3rd ed. New Jersey : Prentice Hall

Ottu, I. F. A., \& Idowu, O. O. (2014). Openness to experience, conscientiousness and gender as personality indicators of career maturity of in-school adolescents in Ibadan, Nigeria. European Journal of Educational Studies, 6(1), 1-12.

Patton, W., Creed, P., Spooner-lane, R., Patton, W., \& Spooner-lane, R. (2005). Validation of the Short Form of the Career Development Inventory - Australian Version with a Sample of University Students. Australian Journal of Career Development, 14(3).

Patton, W., \& Lokan. (2001). Perspectives on Donald Super's construct of career maturity. International Journal for Educational and Vocational Guidance 1: 31-48. Doi: 10.1023/A:1016964629452

Powell, D.F., \& Luzzo, D.A. (1998). 
Evaluating factors associated with the career maturity in high school students. The Career Development Quarterly, 47,145-158

PP No 29 th 1990 tentang Pendidikan Menengah

Prahesty, I. D., \& Mulyana, O.P. (2013). Perbedaan kematangan karir siswa ditinjau dari jenis sekolah. Character, 2(2), 1-7

Prideaux, L.A., \& Creed, P.A. (2001). Career maturity, career decision making self-efficacy and career indecision : A review of the accrued evidence. Australian Journal of Career Development, 10(3), 7-12

Salami, S.O. (2004). Relationship between problem-solving ability and career maturity among high school students in Nigeria. IFE PsychologIA: An International Journal. 12(2), 162-179

Sirohi, V. (2013). Vocational guidance and career maturity among secondary school students: An Indian experience. Proceedings 1st Annual International Interdisciplinary Conference, AIIC 2013, 24-26 April 2013, Azores, Portugal. 381-389

Salami, S. O. (2008). Gender, Identity Status and Career Maturity of Adolescents in Southwest Nigeria. Journal of Social Science, 16(1), 35-49.
Sudjani. (2014). Faktor-faktor yang mempengaruhi kematangan karir siswa sekolah menengah kejuruan negeri di kota Bandung. Prosiding Konvensi Nasional Asosiasi Pendidikan Teknologi dan Kejuruan (APTEKINDO) ke 7. FPTK Universitas Pendidikan Indonesia, Bandung, 13 sd.14 November 2014. ISBN : 978602-72004-0-1

Sugiyono. (2005). Statistika untukpenelitian. Bandung. Alfabeta.

Suherman. (2008). Konsep dan aplikasi bimbingan dan konseling. Bandung. Madani Production

Tjalla, A., Herdi, \& Kustandi, C. (2015). Green education-based model online career counseling "ACIS-Q" to enhance career maturity of vocational schools students. International Journal of Research Studies in Psychology, 4(January), 36 - 42. doi:10.5861/ ijrsp.2015.993

Winkel, W.S. (2012). Bimbingan dan konseling di institusi pendidikan. Jakarta : Grasindo

Winkel, \& Hastuti, S. (2004). Bimbingan dan konseling di institusi pendidikan. Yogyakarta: Media Abadi. 